\title{
Bcr is a substrate for Transglutaminase 2 cross-linking activity
}

Sun-Ju Yi ${ }^{1}$, John Groffen ${ }^{1,2,3}$, Nora Heisterkamp ${ }^{1,2,3^{*}}$

\begin{abstract}
Background: Breakpoint cluster region (Bcr) is a multi-domain protein that contains a C-terminal GTPase activating protein (GAP) domain for Rac. Transglutaminase 2 (TG2) regulates Bcr by direct binding to its GAP domain. Since TG2 has transglutaminase activity that has been implicated in the response to extreme stress, we investigated if $\mathrm{Bcr}$ can also act as a substrate for TG2.

Results: We here report that activation of TG2 by calcium caused the formation of covalently cross-linked Bcr. Abr, a protein related to $\mathrm{Bcr}$ but lacking its N-terminal oligomerization domain, was not cross-linked by TG2 even though it forms a complex with it. A Bcr mutant missing the first 62 amino acid residues remained monomeric in the presence of activated TG2, showing that this specific domain is necessary for the cross-linking reaction. Calcium influx induced by a calcium ionophore in primary human endothelial cells caused cross-linking of endogenous Bcr, which was inhibited by the TG2 inhibitor cystamine. Treatment of cells with cobalt chloride, a hypoxia-mimetic that causes cellular stress, also generated high molecular weight Bcr complexes. Cross-linked Bcr protein appeared in the TritonX-100-insoluble cell fraction and further accumulated in cells treated with a proteasome inhibitor.
\end{abstract}

Conclusions: Bcr thus represents both an interacting partner under non-stressed conditions and a target of transglutaminase activity for TG2 during extreme stress.

\section{Background}

The breakpoint cluster region (Bcr) protein was originally identified as the amino-terminal part of a fusion protein including the Abl tyrosine kinase, which causes chronic myeloid leukemia and $\mathrm{Ph}$-chromosome-positive acute lymphoblastic leukemia. The fusion of Bcr to Abl deregulates the tyrosine kinase activity of Abl [1]. Although the Bcr protein contributes a varying number of domains to the fusion protein, the N-terminal oligomerization domain of $\mathrm{Bcr}$ is considered to be the most critical component that allows the formation of homotetramer $\mathrm{Bcr} / \mathrm{Abl}$ complexes and deregulates the $\mathrm{Abl}$ tyrosine kinase $[2,3]$.

The normal (non-rearranged) $B C R$ gene encodes a multidomain protein. Apart from the oligomerization domain, it additionally contains serine/threonine protein kinase, tandem DH-PH, C2 and GTPase activating

\footnotetext{
* Correspondence: heisterk@hsc.usc.edu

${ }^{1}$ Section of Molecular Carcinogenesis, Division of Hematology/Oncology, Ms\#54, Childrens Hospital Los Angeles, 4650 Sunset Boulevard, Los Angeles CA 90027, USA

Full list of author information is available at the end of the article
}

protein (GAP) domains. The latter domain has a relatively well-described function: it down-regulates the activated GTP-bound conformation of the small G-protein Rac in vitro [4] and in vivo [5,6]. This function is shared by Abr, a related protein that also contains tandem $\mathrm{DH}-\mathrm{PH}, \mathrm{C} 2$ and GAP domains. However, Abr lacks the $\mathrm{N}$-terminal oligomerization domain.

To understand how the GAP activity of Bcr is regulated, we performed a yeast two-hybrid screen with fulllength $\mathrm{Bcr}$ and isolated transglutaminase 2 (TG2), an interesting multi-functional and multi-domain member of the transglutaminase family [7]. Unlike other transglutaminases, it is expressed in a variety of tissues and cells and also undergoes a GTP-binding/GTPase cycle. TG2 is located in the cytosol, in the nucleus, and on the surface of cells [8]. It appears to have multiple functions, including roles in differentiation, apoptosis, signal transduction, adhesion and migration, wound healing, inflammation and phagocytosis of apoptotic cells [8-11]. TG2 can adopt a closed conformation when its C-terminal domain is GTP-bound. We found that this conformation has decreased affinity for binding with Bcr. 
However, in the absence G-nucleotides, TG2 binds to Bcr and is able to inhibit the Bcr GAP activity towards Rac [7].

Transglutaminases exhibit several enzymatic activities. These include transamidation reactions (cross-linking, amine incorporation and acylation) as well as esterification, deamidation and isopeptidase activities [8,12-14]. TG2 is activated in the presence of high concentrations of calcium and converts to an open conformation. However, TG2 transglutaminase activity is latent under normal conditions because the steady-state concentration of calcium in the cytoplasm is low. It only becomes activated under pathogenic conditions and/or extreme cellular stress [15-18].

Because Bcr and TG2 can form a direct protein complex, we considered the possibility that Bcr could also act as a substrate for TG2. We here show that Bcr but not the related Abr protein is a substrate of TG2 in vitro and in cells under conditions of cellular stress. Interestingly, the presence of the $\mathrm{N}$-terminal oligomerization domain in Bcr was responsible for this differential modification, which may lead to its degradation under conditions of extreme stress.

\section{Results}

\section{TG2 cross-links Bcr}

TG2 can adopt alternate conformations depending on the presence of G-nucleotides or calcium. We previously showed that TG2 interacts with Bcr when TG2 is in the open, non-G-nucleotide bound conformation, which is also the conformation adopted in the presence of calcium [7]. Therefore, we investigated whether $\mathrm{Ca}^{2+}$ could affect the interaction between TG2 and Bcr.

As shown in Figure 1A, we pre-incubated TG2 with $\mathrm{Ca}^{2+}$ or with GTP $\gamma$ S, then added GST-BcrGAP, and performed a GST pull-down assay to investigate the binding of Bcr and TG2 by immunoblotting with antibodies to TG2. GTP $\gamma \mathrm{S}$ loading of both guinea pig TG2 as well as recombinant His-tagged TG2 reduced its binding to BcrGAP (Figure 1A), in agreement with our previous results [7].

The presence of calcium is known to activate TG2 and cause auto-crosslinking [19]. Interestingly, in the presence of $\mathrm{Ca}^{2+}$ there was increased binding of the TG2 monomer to BcrGAP and, moreover, the TG2 multimer also was pulled down with BcrGAP (Figure 1A).

Since the transamidase activity of TG2 is $\mathrm{Ca}^{2+}$-dependent, we next assessed whether Bcr is a substrate of TG2. We transfected COS-1 cells with Bcr, added guinea pig liver TG2 to cell lysates, and performed a transglutaminase assay in the presence or absence of $\mathrm{Ca}^{2+}$. As shown in Figure 1B, addition of exogenous TG2 produced high molecular weight Bcr aggregates in a doseand calcium-dependent manner. Also, we observed high

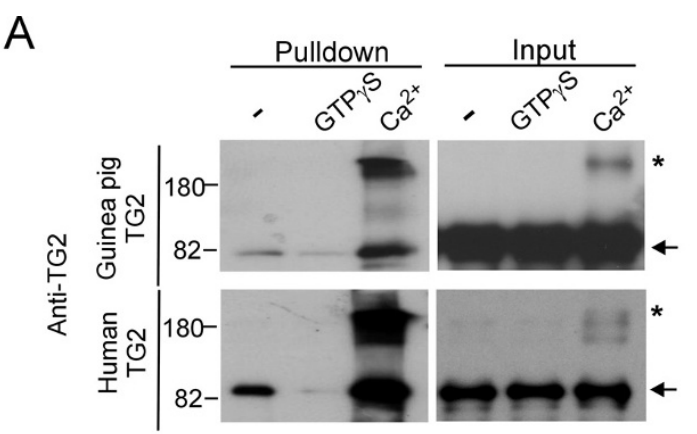

B

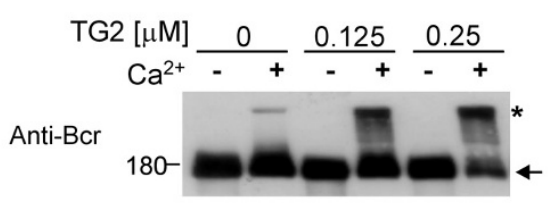

C

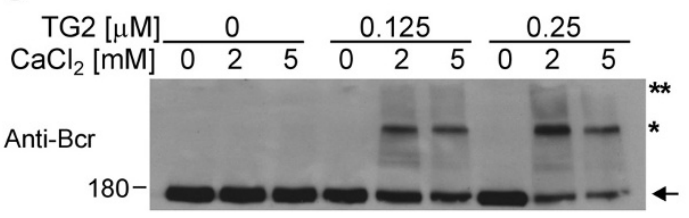

$\mathrm{D}$

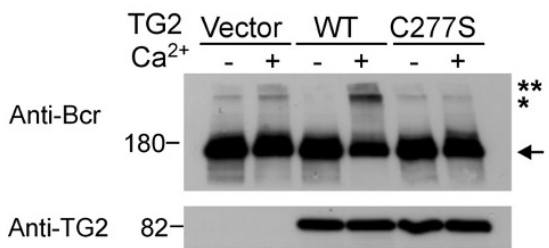

$E$

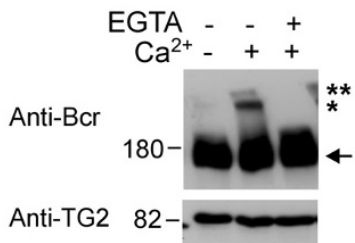

Figure 1 TG2 cross-links Bcr. A) GST-BcrGAP was incubated with guinea pig liver TG2 (Guinea pig TG2) or His-tagged human TG2 (Human TG2) that was loaded with GTP $\gamma$ S, or exposed to $\mathrm{Ca}^{2+}$ or treated with nothing. GST-BCrGAP was pulled down with glutathione-agarose beads and TG2 bound to it detected by Western blot analysis. B) Bcr-transfected COS-1 cell lysates incubated with the indicated amounts of guinea pig TG2 with or without 5 $\mathrm{mM} \mathrm{CaCl} 2$. C) HeLa cell lysates treated with $\mathrm{CaCl}_{2}$ and guinea pig TG2 as indicated. D) COS-1 were transfected with $\mathrm{Bcr}$ and the indicated TG2 constructs. Cell lysates were treated with or without $\mathrm{CaCl}_{2}$. E) Bcr and TG2-transfected cell lysates were incubated with EGTA and/or $\mathrm{CaCl}_{2}$ as indicated for $2 \mathrm{~h}$ at $37^{\circ} \mathrm{C}$. Antibodies used for Western blotting are indicated to the left. Arrows indicate guinea pig TG2 or His $s_{6}$-tagged human TG2 (A) or Bcr monomer (B-E); single asterisks indicate the top of separating gel; double asterisks indicate the wells of the stacking gel. 
molecular weight aggregates of endogenous Bcr in HeLa cell lysates in the presence of guinea pig TG2 (Figure $1 C)$. To investigate if this cross-linked Bcr results from the transglutaminase activity of TG2, TG2 wild type or C277S (a transamidase-defective mutant) and Bcr were co-transfected into COS-1 cells, after which a transamidase assay was performed. As shown in Figure 1D, the TG2 C277S mutant did not induce aggregate formation of Bcr, whereas expression of the wild type TG2 increased the levels of cross-linked Bcr. To confirm that the cross-linking activity is $\mathrm{Ca}^{2+}$-dependent, cell lysates were also pretreated with EGTA, a chelator of $\mathrm{Ca}^{2+}$. Figure 1E shows that the cross-linking reaction was blocked by $5 \mathrm{mM}$ EGTA. These results indicate that Bcr aggregate formation requires transglutaminase activity of TG2 and $\mathrm{Ca}^{2+}$. Since Bcr naturally forms homotetramers, these high molecular weight complexes will consist of Bcr monomers but could also contain TG2, since it was recovered in a pull-down reaction with the Bcr GAP domain (Figure 1A), as well as other unidentified proteins.

\section{Bcr oligomerization domain is required for cross-linking} by TG2

$\mathrm{Bcr}$ is a large protein containing several domains (Figure 2A). Abr (Active Bcr Related) also functions as a GAP for $\mathrm{Rac}$ and is the only protein that shares a high degree of homology with Bcr [20]. The main difference between the two proteins is, that Abr lacks a domain that has homology to the $\mathrm{N}$-terminal end of $\mathrm{Bcr}$. This region in $\mathrm{Bcr}$ includes a serine/threonine kinase domain of unknown significance and a coiled-coil domain that allows Bcr to form tetramers. We previously showed that the Abr GAP domain can bind to TG2 [7]. However, as shown in Figure 2B, Abr was not detectably cross-linked by TG2.

We therefore asked if the N-terminal coiled-coil domain of Bcr could be responsible for allowing TG2 to cross-link Bcr. A construct that lacked the $62 \mathrm{~N}$-terminal amino acids was co-expressed with TG2 and compared to the wild type Bcr protein. As shown in Figure 2B, whereas Xpress-tagged Bcr wild type was cross-linked, the protein lacking the coiled-coil region clearly was not. We confirmed this result by increasing the reaction time or

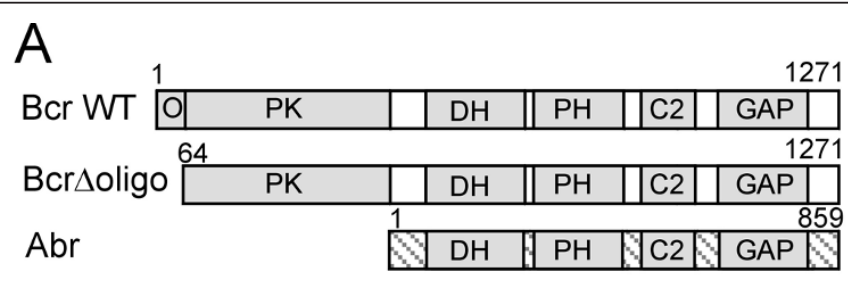

B

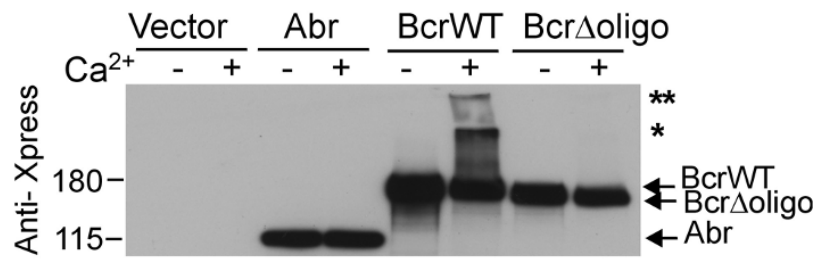

C

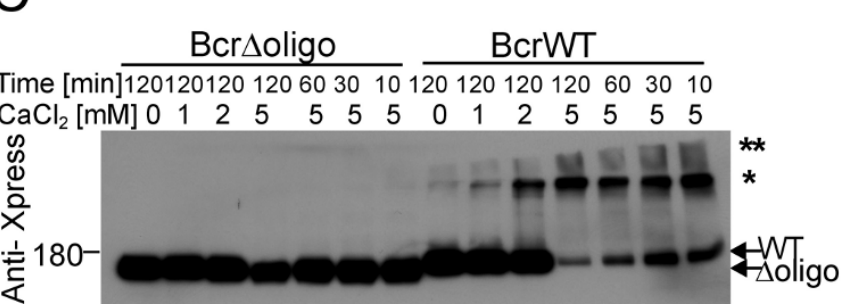

Figure 2 Oligomerization domain of Bcr mediates cross-linking by TG2. A) Schematic view of Bcr and Abr constructs. O, oligomerization domain; PK, protein serine/threonine kinase domain; DH, Dbl homology domain; PH, Pleckstrin homology domain; $\mathrm{C}$, domain with homology to C2 domains that are calcium-dependent, protein or phospholipid binding; GAP, GTPase activating protein. B) Xpress-tagged Abr, Bcr wild type (WT), or Bcr mutant lacking the oligomerization domain ( $\triangle$ oligo) were co-transfected with TG2. Lysates were incubated with or without 5 mM $\mathrm{CaCl}_{2}$. C) Lysates of cells co-transfected with TG2 and Xpress-tagged BcrWT or Bcr $\Delta$ oligo were incubated with $\mathrm{CaCl}_{2}$ for the indicated times. Asterisks, as in Figure 1. 
concentration of $\mathrm{Ca}^{2+}$ : no cross-linking of the Bcr $\Delta$ oligo protein was detected at any length of incubation or concentration of calcium. In contrast, increased concentrations of calcium and prolonged reaction times resulted in progressively increased Bcr appearing in high molecular weight complexes. After 2 hours with $5 \mathrm{mM} \mathrm{CaCl}_{2}$, very little monomeric Bcr remained (Figure $2 \mathrm{C}$ ). These results indicate that the oligomerization domain of $\mathrm{Bcr}$ is crosslinked by TG2.

\section{Bcr is cross-linked in cells under extreme stress}

In the experiments described above, calcium was added to protein lysates. The transglutaminase activity of TG2 can also be activated in the presence of increased levels of intracellular $\mathrm{Ca}^{2+}$. To examine TG2-induced aggregation of Bcr in cells, COS-1 cells were transfected with $\mathrm{Bcr}$ alone or together with TG2 and treated with ionomycin, a calcium ionophore, which induces cell death at high concentrations [21]. As shown in Figure 3A, coexpression of TG2 with Bcr caused a significant increase of high molecular weight Bcr complexes in cells. Ionomycin treatment also caused Bcr cross-linking in cells transfected only with Bcr, likely through activation of endogenous TG2 (Figure 3A, lane Bcr/ionomycin).

To examine cross-linking of endogenous Bcr, we selected primary human pulmonary artery endothelial

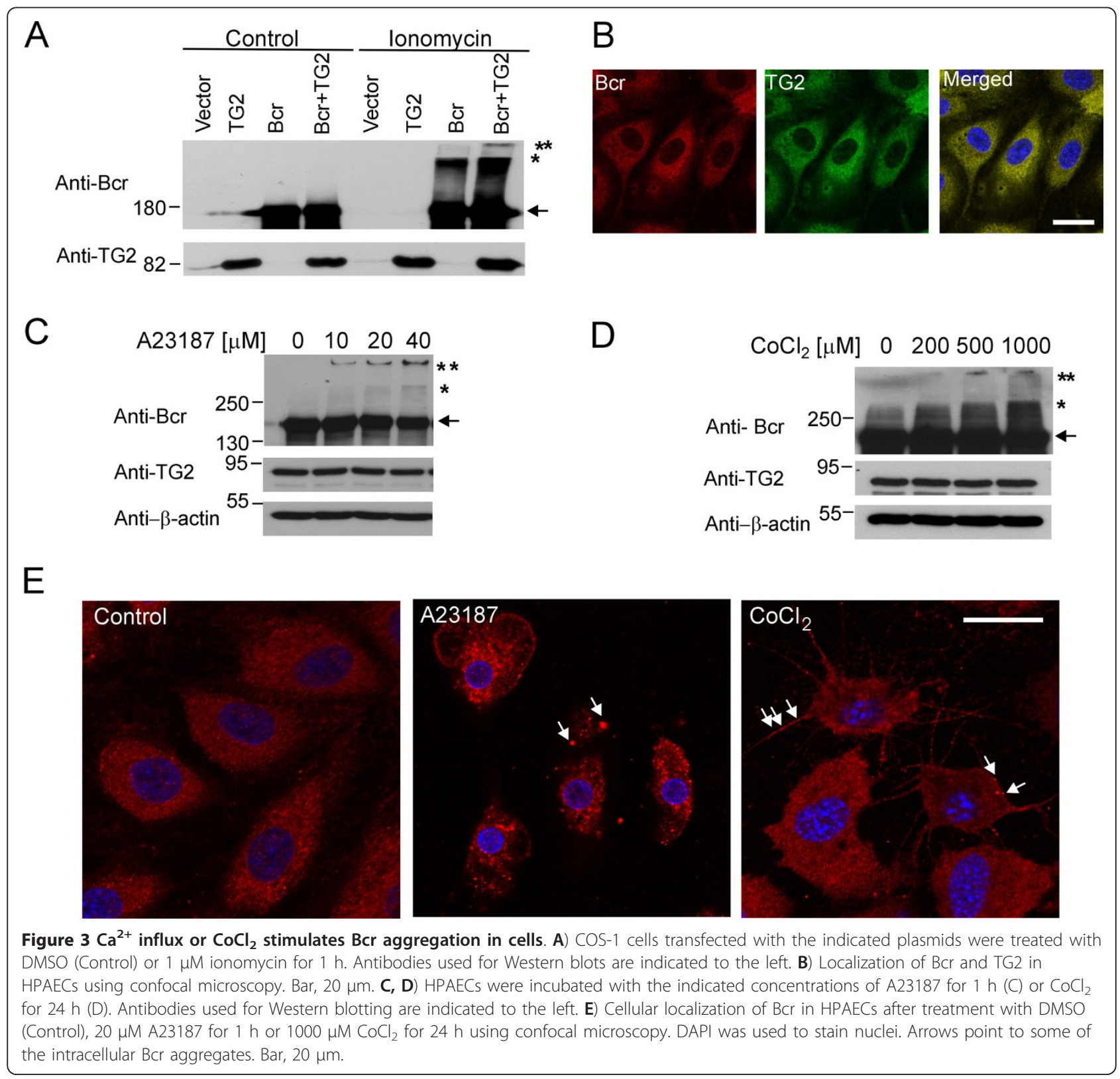


cells (HPAECs), since this cell type expresses substantial amounts of TG2 $[7,22]$. In addition, TG2 plays a role in endothelial cell adhesion, proliferation and apoptosis [23]. As shown in Figure 3B, these cells clearly expressed Bcr protein, and Bcr co-localized with endogenous TG2 in the cytosol. Exposure of HPAEC to A23187, a different calcium ionophore, induced Bcr cross-linking, as was evident by the appearance of high molecular weight Bcr complexes, and this was accompanied by a reduction in the amount of monomers (Figure $3 \mathrm{C})$. These complexes were detected as a smear of Bcrimmunoreactive material at the top of the separation gel and even in the wells of the stacking gel, in an A23187 dose-dependent manner.

$\mathrm{CoCl}_{2}$ is a hypoxia-mimetic agent, because like hypoxia, it can decrease the degradation and cause subsequent accumulation of hypoxia-inducible factor (HIF)$1 \alpha$, a critical regulator of the cellular response to hypoxia [24]. Also, $\mathrm{CoCl}_{2}$ induces cell death [24-28]. It was also recently reported that hypoxia induces the expression of TG2 via HIF- $1 \alpha$ in some cancer cell types, but not in others [29]. To investigate the effect of this type of extreme stress on Bcr cross-linking by TG2, we exposed HPAECs to increasing concentrations of this heavy metal. As shown in Figure 3D, the treatment with high concentrations of $\mathrm{CoCl}_{2}$ caused the appearance high molecular weight Bcr aggregates, suggesting that hypoxic stress can also cause covalent adducts on $\mathrm{Bcr}$. $\mathrm{CoCl}_{2}$ treatment had no effect on the level of TG2 expression in HPAECs (Figure 3D, anti-TG2 Western blot).

Treatment with $\mathrm{A} 23187$ or $\mathrm{CoCl}_{2}$ visibly stressed the cells, which showed signs of apoptosis as determined by FACS (not shown). Consistent with this, DAPI staining showed nuclear condensation and fragmentation (Figure $3 \mathrm{E})$. Interestingly, endogenous Bcr showed a prominent punctuate staining, especially in A23187 treated cells (Figure 3E, arrows). This is consistent with $\mathrm{CoCl}_{2}$ or A23187 causing accumulation of Bcr aggregates in HPAECs that are undergoing cell death.

Cross-linked Bcr is removed by proteasomal degradation As shown in Figure 4A, pretreatment with a competitive TG2 inhibitor, cystamine, dramatically suppressed the appearance of Bcr high molecular weight aggregates, further confirming that the formation of these complexes is dependent on TG2 activity. Since the solubility of some proteins changes after modification by TG2, including monomeric forms and aggregates [30,31], we separated cell lysates into TritonX-100 soluble and insoluble fractions. As shown in Figure 4B, the high molecular weight Bcr aggregates were mainly present in the TritonX-100-insoluble fraction, and more Bcr monomers were present in the TritonX-100-soluble fraction.

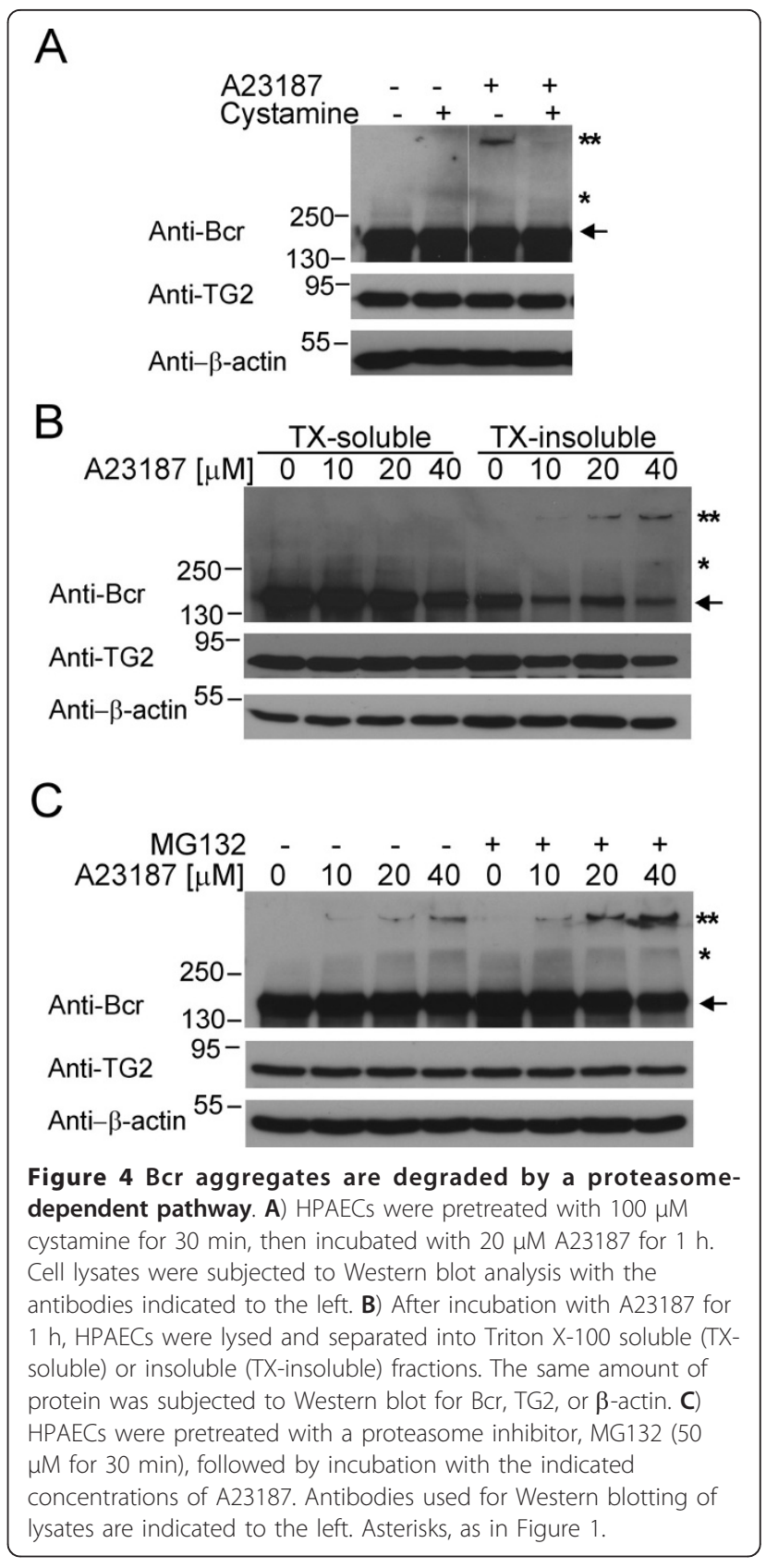

It has been shown that TG2 promotes the proteasomal degradation of some proteins including nucleophosmin and PTEN [31,32]. To investigate if the high molecular weight Bcr aggregates are degraded in a proteasomedependent pathway, HPAECs were pretreated with MG132, a proteasomal inhibitor, before exposure to the calcium ionophore. Interestingly, pretreatment with MG132 caused accumulation of the high molecular weight aggregates of Bcr (Figure 4C). These results suggest that $\mathrm{Bcr}$ aggregates, resulting from cross-linking by TG2, are ultimately disposed of by proteasomal degradation. 


\section{Discussion}

Binding of guanine nucleotides or of $\mathrm{Ca}^{2+}$ to TG2 is known to inversely regulate its conformation and its transglutaminase activity: whereas $\mathrm{Ca}^{2+}$-bound TG2 has an open conformation and is active as a transglutaminase, TG2 bound to G-nucleotides is enzymatically inactive, with a closed conformation [8,16,33]. Although Bcr binds preferentially to the open conformation of TG2, the interaction is not dependent upon TG2 being active as a transglutaminase because the interaction also occurred with the catalytically inactive TG2 C277S mutant [7]. Our current results demonstrate that Bcr also binds quite strongly to the activated, calciumbound form of TG2. Together, these results suggest that under normal physiological conditions, TG2 interacts with $\mathrm{Bcr}$ even though the calcium concentration is not sufficient for activation of the transglutaminase activity. Under conditions of cellular stress caused by high calcium influx, the calcium-bound, enzymatically active form of TG2 then uses Bcr as a substrate for crosslinking.

Apart from high calcium concentrations, other cellular stressors that have been reported to involve TG2 activation include exposure to bacterial endotoxin and glutamate-mediated excitotoxic damage of neuronal cells [34]. However, we did not detect Bcr aggregates in primary rat neurons exposed to glutamate or bone marrow-derived macrophages treated with LPS (not shown). Also, Bcr aggregates were only detected in HPAECs stressed by $\mathrm{CoCl}_{2}$ or $\mathrm{A} 23187$ treatment and not by other stimulants including LPS, TNF- $\alpha$, and thrombin (data not shown). Therefore the formation of Bcr aggregates may be specific only for certain types of cell stress that lead to cell death.

To the best of our knowledge, the biological effect of TG2 cross-linking due to calcium overload has not been conclusively defined for any protein. However, based on what is known about Bcr structure and function, we can envision three possible consequences of Bcr crosslinking under conditions of calcium influx and apoptosis. One is a role that was postulated in general for the consequences of TG2 cross-linking activity under conditions of cell death: TG2 activity could produce a protein-rich "shell" that would prevent leakage of cellular components to the extracellular space and, through this, reduce inflammation that would otherwise be provoked by cell debris [35-37]. Bcr contains a $\mathrm{C} 2$ domain that, in other proteins, is a calcium-binding module. The adjacent $\mathrm{PH}$ domain was recently shown to be able to bind to keratin 10, $\beta$-tubulin and collagen IV [38]. Because the high molecular weight Bcr aggregates found in our study were mainly present in the TritonX-100-insoluble fraction, one could speculate that Bcr, due to multiple cellular interactions including its own capacity to form homo-tetramers, acts as a calcium-induced scaffold for the formation of high molecular weight aggregates including elements of the cytoskeleton. This function would be consistent with the overall activity of Bcr to negatively regulate inflammation in vivo $[6,7]$.

A second speculative role is in the area of vesicle transport. The $\mathrm{PH}$ domain of Bcr was shown to bind to specific mono-phospholipids PtdIns(3)P and PtdIns(4)P that are present in early endosomal membranes and in the Golgi, respectively [38]. Moreover, Bcr binds to the endosomal sorting protein TSG101 [39], which is also present in exosomes [40]. Since cross-linking of Bcr could affect its GAP activity on Rac, this in turn could potentially affect the trafficking of extracellular TG2. Finally, our results suggest that cross-linked Bcr is targeted for degradation. Since Bcr is a negative regulator of Rac, its removal would lead to increased levels of activated Rac, which has been associated with both decreased and increased apoptosis, depending on the cell type.

Bcr contains a unique $\mathrm{N}$-terminal coiled-coil domain that has been a focus of significant interest because it is responsible for deregulation of the tyrosine kinase activity of $\mathrm{Abl}$ within the $\mathrm{Bcr} / \mathrm{Abl}$ fusion protein that causes the development of some types of leukemia. Interestingly, this domain also allows the formation of $\mathrm{Bcr}$ homodimers and tetramers $[2,3,41,42]$. We here found that it plays an important role in the formation of Bcr aggregates. The domain encompasses residues 2-63, which includes two lysine and five glutamine residues that could be involved in the cross-linking reaction, but the exact requirements for cross-linking remain to be determined. It will also be of interest to address if TG2 is able to cross-link the $\mathrm{N}$-terminal oligomerization domain of the Bcr/Abl oncoprotein.

\section{Conclusions}

We recently showed that TG2 directly interacts with Bcr and regulates the GAP activity of Bcr under normal physiological conditions. Here, we present data showing that $\mathrm{Bcr}$ is a substrate for TG2 transglutaminase activity in vitro and in cells. Under extreme stress, TG2 crosslinks Bcr into high molecular weight complexes which are removed by a proteasomal degradation pathway. These results suggest that $\mathrm{Bcr}$ is regulated by TG2 via different mechanisms, depending on the physiological conditions in the cell.

\section{Methods}

\section{Plasmids and Antibodies}

Full length human TG2 wild type, TG2 C277S cDNAs and Xpress-tagged Bcr wild type have been described 
previously [7]. To generate Xpress-tagged $B c r \Delta$ oligo, we isolated the $\mathrm{N}$-terminal end of Bcr with deletion of amino acid residues 2-63 from a previously described $474 \mathrm{bp}$ subclone by digestion with Eag I $\times$ Xho I [43]. The $3.5 \mathrm{~kb} 3$ ' end of $B C R$ was isolated from a cDNA clone in pSK (B1/SK) by digestion with Xho I $\times$ Xba I. These two fragments were combined in pcDNA3.1/HisB digested with Not I $\times$ Xba I. Xpress-tagged Abr was constructed in a 3-way ligation between a 5' $0.45 \mathrm{~kb}$ BamHI-BstEII, a 3' $2.2 \mathrm{~kb}$ BstEII-EcoRI fragment and vector pcDNA/HisC digested with BamHI $\times$ EcoRI. The amino-terminal $\mathrm{Abr}$ end is the one expressed on the non-neuronal isoform. Bcr (N-20), Xpress and TG2 antibodies were from Santa Cruz Biotechnology (Santa Cruz, CA), Invitrogen (Carlsbad, CA) and Lab Vision (Fremont, CA), respectively. MG132 and monoclonal Bcr (Ab-2) antibodies were from EMD Chemicals (Gibbstown, NJ).

\section{Cell culture}

COS-1 and HeLa cells were obtained from the American Type Culture Collection (Manassas, VA). Human pulmonary artery endothelial cells (HPAECs) were from Invitrogen, and were cultured in Medium 200 with low serum growth supplement according to the manufacturer's protocol. They were used at passage 4-6.

\section{GST pull-down assay}

Recombinant GST-BcrGAP and His $_{6}$-tagged human TG2 were purified from $E$. coli as described $[4,44]$. For GTP $\gamma \mathrm{S}$ or $\mathrm{Ca}^{2+}$ loading of TG2 and in vitro binding assays, 12.5 pmol of guinea pig TG2 (Sigma, St. Louise, $\mathrm{MO}$ ) or $\mathrm{His}_{6}$-tagged TG2 was incubated in $25 \mathrm{mM}$ Tris, pH 7.4, 1 mM EGTA, 1 mM EDTA, 1 mM DTT, $2 \mathrm{mM}$ $\mathrm{MgCl}_{2}, 100 \mathrm{mM} \mathrm{NaCl}, 0.1 \%$ Igepal, $1 \mathrm{mM}$ phenylmethylsulfonyl fluoride (PMSF), $10 \mu \mathrm{g} / \mathrm{ml}$ aprotinin, $10 \mu \mathrm{g} / \mathrm{ml}$ leupeptin, $10 \%$ glycerol, and $100 \mu \mathrm{M}$ GTP $\gamma \mathrm{S}$ or $5 \mathrm{mM} \mathrm{CaCl}_{2}$ for $20 \mathrm{~min}$ at $30^{\circ} \mathrm{C} .12 .5 \mathrm{pmol}$ of GSTBcrGAP was added and allowed to form a complex for $1 \mathrm{~h}$ at $4^{\circ} \mathrm{C}$, followed by incubation with glutathioneagarose beads for $1 \mathrm{~h}$ at $4^{\circ} \mathrm{C}$.

\section{Transfection and cross-linking assay}

COS-1 cells were transfected with Plus reagent and Lipofectamine (Invitrogen) according to the manufacturer's instructions and grown for 2 days prior to the assay. For cross-linking assays, cells were lysed in transglutaminase assay buffer (50 mM Tris, $\mathrm{pH} 8.0,150 \mathrm{mM}$ $\mathrm{NaCl}, 1 \%$ Triton X-100, 1 mM DTT, 1 mM PMSF, $10 \mu \mathrm{g} / \mathrm{ml}$ aprotinin, $10 \mu \mathrm{g} / \mathrm{ml}$ leupeptin, $1 \mu \mathrm{g} / \mathrm{ml}$ pepstatin). Cell lysates $(50 \mu \mathrm{g})$ were incubated with or without $5 \mathrm{mM} \mathrm{CaCl}_{2}$ for $2 \mathrm{~h}$ at $37^{\circ} \mathrm{C}$, based on previously reported concentrations of $5 \mathrm{mM}$ or more of $\mathrm{CaCl}_{2}$ added to in vitro assays, using cell extracts or purified proteins $[29,45]$. In some experiments, guinea pig TG2 or EGTA was added to the reactions.

\section{Treatment with calcium ionophores or $\mathrm{CoCl}_{2}$}

Transfected COS-1 cells were treated with $1 \mu \mathrm{M}$ ionomycin for $1 \mathrm{~h}$. HPAECs were treated with 10-40 $\mu \mathrm{M}$ A23187 for $1 \mathrm{~h}$ or with $\mathrm{CoCl}_{2}$ for $24 \mathrm{~h}$ and lysed with SDS lysis buffer (50 mM Tris, pH 6.8, 2\% SDS, 10\% glycerol). For some experiments, cells were pretreated with cystamine or MG132 for 30 min. For separation of TritonX-100-soluble and insoluble fractions, cells were lysed in $50 \mathrm{mM}$ Tris, pH 7.6, $150 \mathrm{mM} \mathrm{NaCl}, 1 \%$ Triton X-100, $5 \mathrm{mM}$ EDTA, $1 \mathrm{mM}$ PMSF, $10 \mu \mathrm{g} / \mathrm{ml}$ aprotinin, $10 \mu \mathrm{g} / \mathrm{ml}$ leupeptin, $1 \mu \mathrm{g} / \mathrm{ml}$ pepstatin and centrifuged at $16000 \mathrm{~g}$ for $15 \mathrm{~min}$. The supernatants were collected as TritonX-100-soluble fractions and insoluble pellets were solubilized in SDS lysis buffer as TritonX-100 insoluble fractions.

\section{Immunofluorescence}

HPAECs were grown on fibronectin-coated coverslips (Fisher Scientific) for 1-2 days and then treated with A23187 or $\mathrm{CoCl}_{2}$. Cells were washed twice with PBS and fixed in 4\% paraformaldehyde (Electronic Scientific Co., Hatfield, PA) (15 min at room temperature [RT]), followed by permeabilization in $0.2 \%$ Triton X-100 (15 min, RT). Cells were blocked in $1 \%$ bovine serum albumin in PBS and stained with TG2 antibodies (Lab vision $\mathrm{Ab}-4,5 \mu \mathrm{g} / \mathrm{ml}$ ) and Bcr antibodies (EMD chemicals $\mathrm{Ab}-2,1 \mu \mathrm{g} / \mathrm{ml}$ ) in blocking solution overnight at $4^{\circ} \mathrm{C}$, followed by incubation with Cy3-conjugated antimouse IgG and FITC-conjugated anti-rabbit IgG antibodies (Jackson ImmunoResearch Laboratories, Inc, West Grove, PA). After mounting in Vectashield containing 4',6'-diamidino-2-phenylindole (DAPI; Vector Laboratories, Burlingame, CA), cell images were acquired with a Zeiss 710 confocal microscope.

\section{Abbreviations}

Bcr: breakpoint cluster region; TG2: transglutaminase 2; GAP: GTPase activating protein; HPAECs: human pulmonary artery endothelial cells; PMSF: phenylmethylsulfonyl fluoride; RT: room temperature; DAPI: 4',6'-diamidino-2phenylindole; DMSO: dimethyl sulfoxide.

\section{Acknowledgements}

Gail V.W. Johnson (U. of Rochester) is acknowledged for the generous gift of the TG2 wild-type and C277S clones. We thank Young Jin Cho for making the Xpress-Abr construct. We also thank G. Esteban Fernandez (Cellular Imaging Core, Childrens Hospital Los Angeles) for confocal microscopy. This work was supported by National Institutes of Health, Public Health Service grants HL071945, HL060231 and CA090321.

\section{Author details}

${ }^{1}$ Section of Molecular Carcinogenesis, Division of Hematology/Oncology, Ms\#54, Childrens Hospital Los Angeles, 4650 Sunset Boulevard, Los Angeles CA 90027, USA. ${ }^{2}$ The Saban Research Institute of Childrens Hospital Los 
Angeles, CA 90027, USA. ${ }^{3}$ Department of Pathology, Keck School of Medicine, University of Southern California, Los Angeles, CA 90033, USA.

\section{Authors' contributions}

SY participated in the study design, performed all experiments described here and wrote a draft of the manuscript. JG contributed ideas for experiments; $\mathrm{NH}$ participated in study design, provided ideas for experiments and wrote the manuscript. All authors read and approved the final manuscript.

Received: 20 October 2010 Accepted: 10 February 2011 Published: 10 February 2011

\section{References}

1. Groffen J, Heisterkamp N: The chimeric BCR-ABL gene. Baillieres Clin Haematol 1997, 10:187-201.

2. McWhirter JR, Galasso DL, Wang JY: A coiled-coil oligomerization domain of $\mathrm{Bcr}$ is essential for the transforming function of Bcr-Abl oncoproteins. Mol Cell Biol 1993, 13:7587-7595.

3. McWhirter JR, Wang JY: Effect of Bcr sequences on the cellular function of the Bcr-Abl oncoprotein. Oncogene 1997, 15:1625-1634.

4. Chuang TH, Xu X, Kaartinen V, Heisterkamp N, Groffen J, Bokoch GM: Abr and $\mathrm{BCr}$ are multifunctional regulators of the Rho GTP-binding protein family. Proc Natl Acad Sci USA 1995, 92:10282-10286.

5. Cho YJ, Cunnick JM, Yi SJ, Kaartinen V, Groffen J, Heisterkamp N: Abr and Bcr, two homologous Rac GTPase-activating proteins, control multiple cellular functions of murine macrophages. Mol Cell Biol 2007, 27:899-911.

6. Cunnick JM, Schmidhuber S, Chen G, Yu M, Yi SJ, Cho YJ, Kaartinen V, Minoo P, Warburton D, Groffen J, Heisterkamp N: Bcr and Abr cooperate in negatively regulating acute inflammatory responses. Mol Cell Biol 2009, 29:5742-5750

7. Yi SJ, Groffen J, Heisterkamp N: Transglutaminase 2 regulates the GTPaseactivating activity of Bcr. J Biol Chem 2009, 284:35645-35651.

8. Fésüs $L$, Piacentini M: Transglutaminase 2 : an enigmatic enzyme with diverse functions. Trends Biochem Sci 2002, 27:534-539.

9. Kim SY: Transglutaminase 2 in inflammation. Front Biosci 2006 , 11:3026-3035.

10. Zemskov EA, Janiak A, Hang J, Waghray A, Belkin AM: The role of tissue transglutaminase in cell-matrix interactions. Front Biosci 2006, 11:1057-1076.

11. Tóth B, Garabuczi E, Sarang Z, Vereb G, Vámosi G, Aeschlimann D, Blaskó B, Bécsi B, Erdõdi F, Lacy-Hulbert A, Zhang A, Falasca L, Birge RB, Balajthy Z, Melino G, Fésüs L, Szondy Z: Transglutaminase 2 is needed for the formation of an efficient phagocyte portal in macrophages engulfing apoptotic cells. J Immunol 2009, 182:2084-2092.

12. Mishra S, Murphy $\amalg$ : Tissue transglutaminase has intrinsic kinase activity: identification of transglutaminase 2 as an insulin-like growth factorbinding protein-3 kinase. J Biol Chem 2004, 279:23863-23868.

13. Hasegawa G, Suwa M, Ichikawa Y, Ohtsuka T, Kumagai S, Kikuchi M, Sato $Y$, Saito $Y$ : A novel function of tissue-type transglutaminase: protein disulphide isomerase. Biochem J 2003, 373:793-803.

14. Lorand L, Graham RM: Transglutaminases: cross-linking enzymes with pleiotropic functions. Nat Rev Mol Cell Biol 2003, 4:140-156.

15. Lorand L, Weissmann LB, Epel DL, Bruner-Lorand J: Role of the intrinsic transglutaminase in the Ca2+-mediated crosslinking of erythrocyte proteins. Proc Natl Acad Sci USA 1976, 73:4479-4481.

16. Pinkas DM, Strop P, Brunger AT, Khosla C: Transglutaminase 2 undergoes a large conformational change upon activation. PLoS Biol 2007, 5:e327.

17. Siegel M, Khosla C: Transglutaminase 2 inhibitors and their therapeutic role in disease states. Pharmacol Ther 2007, 115:232-245.

18. Gundemir S, Johnson G: Intracellular localization and conformational state of transglutaminase 2: implications for cell death. PLoS One 2009, 4 e6123.

19. Birckbichler PJ, Orr GR, Carter HA, Patterson MK Jr: Catalytic formation of $\varepsilon$ ( $\gamma$-glutamyl)lysine in guinea pig liver transglutaminase. Biochem Biophys Res Commun 1977, 78:1-7.

20. Heisterkamp N, Kaartinen V, van Soest S, Bokoch GM, Groffen J: Human $A B R$ encodes a protein with GAPrac activity and homology to the DBL nucleotide exchange factor domain. J Biol Chem 1993, 268:16903-16906.

21. Gwag BJ, Canzoniero LM, Sensi SL, Demaro JA, Koh JY, Goldberg MP, Jacquin M, Choi DW: Calcium ionophores can induce either apoptosis or necrosis in cultured cortical neurons. Neuroscience 1999, 90:1339-1348.
22. Korner G, Schneider DE, Purdon MA, Bjornsson TD: Bovine aortic endothelial cell transglutaminase. Enzyme characterization and regulation of activity. Biochem J 1989, 262:633-641.

23. Nadalutti C, Viiri KM, Kaukinen K, Mäki M, Lindfors K: Extracellular transglutaminase 2 has a role in cell adhesion, whereas intracellular transglutaminase 2 is involved in regulation of endothelial cell proliferation and apoptosis. Cell Prolif 2011, 44:49-58.

24. Guo M, Song LP, Jiang Y, Liu W, YU Y, Chen GQ: Hypoxia-mimetic agents desferrioxamine and cobalt chloride induce leukemic cell apoptosis through different Hypoxia-inducible factor-1a independent mechanisms. Apoptosis 2006, 11:67-77.

25. Yang SJ, Pyen J, Lee I, Lee H, Kim Y, Kim T: Cobalt chloride-induced apoptosis and extracellular signal-regulated protein kinase $1 / 2$ activation in rat C6 glioma cells. J Biochem Mol Biol 2004, 3:480-486.

26. Araya J, Maruyama M, Inoue A, Fujita T, Kawahara J, Sassa K, Hayashi R, Kawagishi Y, Yamashita N, Sugiyama E, Kobayashi M: Inhibition of proteasome activity is involved in cobalt-induced apoptosis of human alveolar macrophages. Am J Physiol Lung Cell Mol Physiol 2002, 283. L849-858.

27. Wang G, Hazra TK, Mitra S, Lee HM, Englander EW: Mitochondrial DNA damage and a hypoxic response are induced by $\mathrm{CoCl}_{2}$ in rat neuronal PC12 cells. Nucleic Acids Res 2000, 28:2135-2140.

28. Vengellur A, LaPres JJ: The role of hypoxia inducible factor 1alpha in cobalt chloride induced cell death in mouse embryonic fibroblasts. Toxicol Sci 2004, 82:638-646.

29. Jang GY, Jeon JH, Cho SY, Shin DM, Kim CW, Jeong EM, Bae HC, Kim TW, Lee SH, Choi Y, Lee DS, Park SC, Kim IG: Transglutaminase 2 suppresses apoptosis by modulating caspase 3 and NF-kappaB activity in hypoxic tumor cells. Oncogene 2010, 29:356-367.

30. Shin DM, Jeon JH, Kim CW, Cho SY, Kwon JC, Lee HJ, Choi KH, Park SC, Kim IG: Cell type-specific activation of intracellular transglutaminase 2 by oxidative stress or ultraviolet irradiation: implications of transglutaminase 2 in age-related cataractogenesis. J Biol Chem 2004, 279:15032-15039.

31. Park K, Han B, Lee K, Kim D, Kim J, Jeon H, Kim HS, Suh SW, Lee EH, Kim S, Lee $B$ : Depletion of nucleophosmin via transglutaminase 2 cross-linking increases drug resistance in cancer cells. Cancer Lett 2009, 274:201-207.

32. Verma A, Guha S, Wang H, Fok JY, Koul D, Abbruzzese J, Mehta K: Tissue transglutaminase regulates focal adhesion kinase/AKT activation by modulating PTEN expression in pancreatic cancer cells. Clin Cancer Res 2008, 14:1997-2005.

33. Begg GE, Carrington L, Stokes PH, Matthews JM, Wouters MA, Husain A, Lorand L, lismaa SE, Graham RM: Mechanism of allosteric regulation of transglutaminase 2 by GTP. Proc Natl Acad Sci USA 2006, 103:19683-19688.

34. Ientile $R$, Caccamo D, Griffin M: Tissue transglutaminase and the stress response. Amino Acids 2007, 33:385-394.

35. Fésüs $L$, Szondy Z: Transglutaminase 2 in the balance of cell death and survival. FEBS Lett 2005, 579:3297-302

36. Park D, Choi SS, Ha KS: Transglutaminase 2: a multi-functional protein in multiple subcellular compartments. Amino Acids 2010, 39:619-631.

37. Nicholas B, Smethurst P, Verderio E, Jones R, Griffin M: Cross-linking of cellular proteins by tissue transglutaminase during necrotic cell death: $a$ mechanism for maintaining tissue integrity. Biochem J 2003, 371:413-422.

38. Miroshnychenko D, Dubrovska A, Maliuta S, Telegeev G, Aspenström P: Novel role of pleckstrin homology domain of the Bcr-Abl protein: analysis of protein-protein and protein-lipid interactions. Exp Cell Res 2010, 316:530-542

39. Olabisi OO, Mahon GM, Kostenko EV, Liu Z, Ozer HL, Whitehead IP: Bcr interacts with components of the endosomal sorting complex required for transport-I and is required for epidermal growth factor receptor turnover. Cancer Res 2006, 66:6250-6257.

40. Ogawa Y, Miura Y, Harazono A, Kanai-Azuma M, Akimoto Y, Kawakami H, Yamaguchi T, Toda T, Endo T, Tsubuki M, Yanoshita R: Proteomic analysis of two types of exosomes in human whole saliva. Biol Pharm Bull 2011, 34:13-23.

41. Beissert T, Puccetti E, Bianchini A, Güller S, Boehrer S, Hoelzer D, Ottmann OG, Nervi C, Ruthardt M: Targeting of the N-terminal coiled coil oligomerization interface of $\mathrm{BCR}$ interferes with the transformation potential of BCR-ABL and increases sensitivity to STI571. Blood 2003, 102:2985-2993. 
42. Zhao X, Ghaffari S, Lodish H, Malashkevich VN, Kim PS: Structure of the Bcr-Abl oncoprotein oligomerization domain. Nat Struct Biol 2002, 9:117-120.

43. Heisterkamp N, Voncken JW, Senadheera D, Hemmeryckx B, GonzalezGomez I, Reichert A, Pattengale PK, Groffen J: The Bcr N-terminal oligomerization domain contributes to the full oncogenicity of P190 Bcr/ Abl in transgenic mice. Int J Mol Med 2001, 7:351-357.

44. Datta S, Antonyak MA, Cerione RA: Importance of $\mathrm{Ca}^{2+}$-dependent transamidation activity in the protection afforded by tissue transglutaminase against doxorubicin-induced apoptosis. Biochemistry 2006, 45:13163-13174.

45. Park SS, Kim JM, Kim DS, Kim IH, Kim SY: Transglutaminase 2 mediates polymer formation of I-kB through C-terminal glutamine cluster. J Biol Chem 2006, 281:34965-34972.

doi:10.1186/1471-2091-12-8

Cite this article as: $\mathrm{Yi}$ et al.: Bcr is a substrate for Transglutaminase 2 cross-linking activity. BMC Biochemistry 2011 12:8.

\section{Submit your next manuscript to BioMed Central} and take full advantage of:

- Convenient online submission

- Thorough peer review

- No space constraints or color figure charges

- Immediate publication on acceptance

- Inclusion in PubMed, CAS, Scopus and Google Scholar

- Research which is freely available for redistribution

Submit your manuscript at www.biomedcentral.com/submit
Ciomed Central 